\title{
Evaluasi Genotipe Tomat Hasil Iradiasi Sinar Gamma di Dataran Rendah
}

\author{
Evaluation of Tomato Genotype Resulted from Gamma Irradiation in the Lowland
}

\author{
Muhammad Roiyan Romadhon ${ }^{1}$, Surjono Hadi Sutjahjo ${ }^{2 *}$, dan Siti Marwiyah ${ }^{2}$ \\ ${ }^{1}$ Program Studi Pemuliaan dan Bioteknologi Tanaman, Sekolah Pascasarjana, Institut Pertanian Bogor \\ ${ }^{2}$ Departemen Agronomi dan Hortikultura, Fakultas Pertanian, Institut Pertanian Bogor \\ (Bogor Agricultural University), Jl. Meranti, Kampus IPB Darmaga, Bogor 16680, Indonesia
}

Diterima 3 Agustus 2017/Disetujui 3 Juli 2018

\begin{abstract}
Bacterial wilt and fruit cracking are serious problems in tomatoes cultivation in the lowland area. This research aimed to evaluate the yield of M4 generation of tomatoes in the field and the incidence of bacterial wilt disease and fruit cracking in low altitude. The research was conducted at the IPB Experimental Field in Leuwikopo, Dramaga, Bogor, from December 2015 to April 2016. The experiment used a randomized complete block design with three replications. The material consisted of 15 M4 genotypes and two controls (Berlian and Kefaminano 6). The results showed that genotype of M4/495 Lombok 1-9-2 (U2) has high productivity. Genotype M4/990 Lombok 1-5-1 (U1) has high weight per fruit and resistant to fruit cracking. Genotype M4/495 GL2-8-10 (U2), M4/495 Kemir 1- 4-7 (U3), M4/495 STBGL 1-2-3 (U1) M4/990 Lombok 1-5-1 (U1), and M4/495 STBGL 1-2-9 (U1) have the lowest incidence of bacterial wilt (0.00\%). Two genotypes which have high productivity and resistant to fruit cracking are M4/495 Lombok 1-9-2 (U2) and M4/990 Lombok 1-5-1 (U1), and to be evaluated in a preliminary yield trial.
\end{abstract}

Keywords: bacterial wilt, fruit cracking, genotype, yield

\section{ABSTRAK}

Serangan layu bakteri dan pecah buah merupakan ancaman serius dalam budidaya tomat di dataran rendah. Penelitian ini bertujuan untuk mengevaluasi genotipe tomat tahan terhadap layu bakteri dan pecah buah di dataran rendah. Penelitian ini dilakukan di Kebun Percobaan Leuwikopo IPB, Dramaga, Bogor, pada bulan Desember 2015 hingga April 2016. Percobaan menggunakan rancangan kelompok lengkap teracak dengan tiga ulangan. Bahan penelitian terdiri atas 15 genotipe M4 dan dua pembanding (Berlian dan Kefaminano 6). Hasil percobaan menunjukkan bahwa genotipe yang memiliki produktivitas tinggi yaitu genotipe M4/495 Lombok 1-9-2 (U2). Genotipe M4/990 Lombok 1-5-1 (U1) memiliki bobot per buah yang tinggi serta tahan pecah buah. Genotipe M4/495 GL2-8-10 (U2), M4/495 Kemir 1- 4-7 (U3), M4/495 STBGL 1-2-3 (U1) M4/990 Lombok 1-5-1 (U1), dan M4/495 STBGL 1-2-9 (U1) memiliki persentase kejadian penyakit layu bakteri paling rendah (0.00 \%). Dua genotipe M4 dengan produktivitas yang tinggi dan tahan pecah buah yaitu M4/495 Lombok 1-9-2 (U2) dan M4/990 Lombok 1-5-1 (U1) yang dapat dilanjutkan ke uji daya hasil pendahuluan.

Kata kunci: daya hasil, genotipe, layu bakteri, pecah buah

\section{PENDAHULUAN}

Tanaman tomat merupakan salah satu komoditas hortikultura yang bernilai ekonomi tinggi serta penting untuk menunjang ketersediaan pangan dan kecukupan gizi masyarakat. Sugito et al. (2010) menyatakan, tomat mengandung sedikit asam serta mengandung banyak

\footnotetext{
* Penulis untuk korespondensi. e-mail: surjonohadisutjahjo@ yahoo.com
}

bioflavonoid (termasuk likopen, $\alpha$ dan $\beta$-karoten), protein, lemak, vitamin A, C dan sedikit vitamin B. Indonesia masih melakukan impor tomat sebesar 9,411.578 ton baik dalam bentuk olahan, maupun tomat segar dengan nilai 307,893 US\$ (Pusdatin, 2014). Cahyono (2008) menyatakan bahwa pertumbuhan tomat membutuhkan iklim yang dingin dan kering agar kualitas dan produksinya tinggi. Tanaman tomat dapat tumbuh baik di berbagai ketinggian yaitu dataran rendah (0-200 m dpl), dataran medium (200-500 m dpl), dan dataran tinggi (500-700 m dpl). Suhu dan kelembaban tinggi di dataran rendah kurang baik terhadap pertumbuhan, 
produksi, dan kualitas buah. Perubahan cuaca yang sering terjadi dapat berdampak negatif terhadap pertumbuhan dan menyebabkan munculnya berbagai penyakit.

Salah satu cara untuk menghadapi kondisi lingkungan di dataran rendah adalah penggunaan varietas yang tahan penyakit dan toleran pecah buah. Menurut Chaudhry dan Rashid (2011), rendahnya produksi tomat disebabkan oleh budidaya yang tidak sesuai, pertanaman monokultur, penggunaan benih yang tidak bersertifikat, serta cekaman biotik dan abiotik. Apriastika et al. (2015) menyatakan bahwa kelembaban tanah memiliki hubungan yang positif dengan persentase layu penyakit. Suhu yang tinggi akan meningkatkan jumlah layu bakteri pada tanaman. Tingkat serangan berat penyakit ini dapat menyebabkan kematian tanaman. Loreti et al. (2008) menyatakan bahwa tanaman tomat yang terkena layu bakteri akan tumbuh akar adventif dari batang. Karakteristik layu bakteri pada tomat ditandai dengan daun muda layu permanen dan biasanya terjadi pada musim kemarau (Vanitha et al., 2009). Zainal et al. (2011) menyatakan bahwa koleksi genotipe-genotipe dilakukan sebagai langkah awal untuk perakitan kultivar tahan cekaman biotik. Tujuan pengembangan tomat kedepan adalah merakit varietas tomat yang dapat beradaptasi baik di dataran rendah, toleran terhadap pecah buah dan tahan terhadap layu bakteri (Sutjahjo et al., 2015).

Metode pemuliaan dengan menggunakan aplikasi teknologi nuklir (induced mutation) telah umum digunakan dalam proses rekayasa keragaman genetik tanaman menyerbuk sendiri. Induksi mutasi berguna untuk mengubah suatu sifat atau karakter target tanpa mengubah latar belakang genetik tanaman. Induksi mutasi efektif untuk meningkatkan keragaman sumber daya genetik yang digunakan dalam perbaikan varietas tanaman (Gnanamurthy et al., 2012).

Keuntungan menggunakan sinar gamma adalah dosis yang digunakan lebih akurat dan penetrasi penyinaran ke dalam sel bersifat homogen. Induksi mutasi menggunakan iradiasi menghasilkan mutan paling banyak (sekitar 75\%) jika dibandingkan menggunakan perlakuan lainnya seperti mutagen kimia (Chahal dan Gosal, 2006). Peluang kejadian mutasi tergolong kecil tetapi memiliki potensi yang besar karena sumber perubahan berbasis pada masing-masing lokus (Sellammal dan Maheswaran, 2013). Mutasi akibat dari iradiasi sinar gamma dibedakan menjadi mutasi kecil (mutasi gen) dan mutasi besar (mutasi kromosom). Mutasi kecil menyebabkan perubahan susunan molekul gen (DNA), sedangkan lokus gennya tetap. Mutasi besar adalah perubahan yang terjadi pada struktur dan susunan kromosom. Mutasi gen disebut juga mutasi titik. Mutasi ini terjadi karena perubahan urutan basa nukleotida (Lestari, 2012).

Penelitian mengenai mutasi dengan sinar gamma juga dilakukan pada tanaman kentang untuk mendapatkan pertumbuhan dan perkembangan umbi kentang yang lebih besar (Suharjo et al., 2010). Pengaruh bahan mutagen, khususnya radiasi paling banyak terjadi pada koromosom tanaman sehingga mengakibatkan benang kromosom rusak. Pemuliaan dengan mutagen sinar gamma berdampak pada keragaman pada buah tomat untuk sifat umur berbunga, jumlah tandan per tanaman, jumlah buah per tandan, berat buah, ukuran (diameter dan panjang) buah, jumlah rongga buah, dan tingkat kekerasan buah (Damayanti et al., 2007).

Perluasan area tanam di dataran rendah yang tidak sesuai dengan lingkungan tumbuh mendorong timbulnya penyakit layu bakteri dan pecah buah yang menyebabkan penurunan kualitas dan produksi buah tomat. Penyebaran penyakit layu bakteri dapat melalui tanah, air, luka pada akar akibat nematoda atau alat pertanian (Supriadi, 2011). Upaya untuk perbaikan daya hasil dan toleransi terhadap pecah buah dan layu bakteri dapat dilakukan dengan induksi mutasi menggunakan sinar gamma. Oleh sebab itu penelitian ini bertujuan untuk mengevaluasi genotipe tomat tahan terhadap layu bakteri dan pecah buah tomat di dataran rendah sehingga menghasilkan produktivitas tinggi.

\section{BAHAN DAN METODE}

Penelitian dilaksanakan di Kebun Percobaan IPB di Leuwikopo, Laboratorium Pascapanen, dan Laboratorium Pemuliaan Tanaman, Institut Pertanian Bogor. Penelitian dilaksanakan selama 5 bulan, mulai dari bulan Desember 2015 sampai dengan April 2016. Bahan yang digunakan dalam penelitian ini adalah 15 genotipe M4 hasil iradiasi sinar gamma dengan dosis 495 Gy dan 990 Gy serta dua varietas pembanding (Berlian dan Kefaminano 6). Varietas Berlian adalah varietas yang berdaya hasil tinggi dengan bentuk buah bulat dan vareitas Kefaminano 6 sebagai varietas yang tahan layu bakteri dengan bentuk buah pipih. Sembilan genotipe M4 tanaman tomat berbuah bulat yaitu M4/495 Aceh 5- 4-10 (U1), M4/495 Berlian 1-4-1 (U3), M4/495 CLN 1-2-2 (U3), M4/495 Lombok 1-9-2 (U2), M4/990 Lombok 1-5-1 (U1), M4/495 Kemir1-4-7 (U3), M4/495 STBBK 1-2-3 (U3), M4/495 Lombok 4-1-3 (U2), M4/495 Lombok 4-1-3 (U3) serta 6 genotipe M4 yang masuk kelompok berbuah pipih, yaitu M4/495 Lombok 12-2 (U2), M4/495 STBGL 1-2-3 (U1), M4/495 GL 2-8-10 (U2), M4/495 Kefaminano 6-4-3 (U3), M4/990 Kudamati 1-1-1 (U1), dan M4/990 STBGL 1-2-9 (U1). Rancangan percobaan yang digunakan adalah rancangan kelompok lengkap teracak (RKLT), dimana setiap genotipe ditanam dengan tiga ulangan. Data dianalisis melalui analisis ragam dan uji lanjut Dunnett.

Setiap genotipe yang diuji ditanam pada plot berukuran panjang $5 \mathrm{~cm}$ dan lebar $1 \mathrm{~m}$. Setiap plot terdapat 20 tanaman dengan 10 tanaman sebagai contoh kecuali varietas pembanding hanya 5 tanaman contoh. Tanaman tomat ditanam dengan jarak tanam $40 \mathrm{~cm} \mathrm{x} 40 \mathrm{~cm}$. Dosis pupuk yang digunakan adalah pupuk kandang sebanyak

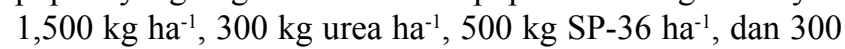
$\mathrm{kg} \mathrm{KCl} \mathrm{ha-1}$. Pengendalian hama dan penyakit dilaksanakan secara kimiawi sesuai dengan serangan, jenis hama, dan penyakit yang menyerang tanaman tomat, yaitu fungisida 
mankozeb $80 \%$ atau propineb $2 \mathrm{~g} \mathrm{~L}^{-1}$, serta insektisida prevonofos dengan dosis $2 \mathrm{~mL} \mathrm{~L}^{-1}$. Pemanenan dilakukan setiap minggu selama enam kali panen terhadap buah tomat yang sudah memperlihatkan kriteria kematangan minimal $75 \%$ berwarna merah. Karakter yang diamati adalah tinggi tanaman, diameter batang, umur berbunga, umur panen, panjang buah, diameter buah, padatan terlarut total (PTT), bobot per buah, bobot buah per tanaman, produktivitas, bobot buah pecah, dan indeks pecah buah; selain peubah tersebut juga dilakukan pengamatan pada serangan layu bakteri yaitu kejadian penyakit berdasarkan tanaman yang mati akibat inokulasi layu bakteri. Perhitungan tingkat kejadian penyakit pada tanaman dilakukan dengan cara mengamati gejala eksternal pada tanaman. Menurut Agrios (1996), perhitungan dilakukan setiap minggu setelah timbulnya gejala awal. Tingkat kejadian penyakit dihitung rumus sebagai berikut: $\mathrm{KP}=\frac{\mathrm{n}}{\mathrm{N}} \times 100 \%$

Keterangan:

$\mathrm{KP}=$ tingkat kejadian penyakit $(\%), \mathrm{n}=$ jumlah tanaman layu yang diamati, $\mathrm{N}=$ jumlah tanaman yang diamati.

\section{HASIL DAN PEMBAHASAN}

Penelitian ini menunjukkan bahwa hasil sidik ragam keragaan pecah buah (persentase bobot buah pecah dan indeks pecah buah), keragaan komponen hasil (tinggi tanaman, diameter batang, umur berbunga, dan umur panen), keragaan hasil (jumlah buah per tanaman, bobot buah per tanaman, bobot per buah, panjang buah, diameter buah, padatan terlarut total, dan produktivitas), keragaan ketahanan terhadap layu bakteri (kejadian penyakit) dipengaruhi oleh genotipe (Tabel 1).
Keragaan Karakter Tinggi Tanaman, Diameter Batang, Umur Berbunga, dan Umur Panen Setiap Genotipe

Tinggi tanaman dan diameter batang diamati pada saat tanaman mulai berbuah karena pada saat tersebut telah mencapai pertumbuhan maksimal. Tinggi tanaman diukur pada umur 12 MST (panen kedua). Hossain et al. (2012) menyatakan bahwa suhu yang tinggi mengakibatkan tinggi tanaman menjadi lebih rendah dibanding dengan kondisi suhu rendah. Tinggi rata-rata tanaman yang dikelompokkan berbuah pipih lebih tinggi dibandingkan tanaman berbuah bulat. Tinggi tanaman berbuah pipih berkisar 121.33-143.33 $\mathrm{cm}$, sementara tinggi tanaman berbuah bulat antara 52.67$107.67 \mathrm{~cm}$ (Tabel 2).

Tanaman tomat berbuah pipih termasuk tanaman dengan tipe pertumbuhan indeterminat sedangkan tanaman tomat berbuah bulat termasuk tipe pertumbuhan determinat. Genotipe M4/495 STBBK 1-2-3 (U3) merupakan genotipe kelompok buah pipih yang paling tinggi serta mempunyai tinggi yang sama dengan tinggi tanaman Berlian sebagai pembanding. Genotipe M4/495 STBGL 1-2-3 (U1) memiliki tinggi tanaman kelompok buah bulat paling tinggi dibanding dengan pembanding Kefaminano 6 (Tabel 2). Nazirwan et al. (2014) menyatakan bahwa perbedaan karakter tinggi tanaman dipengaruhi oleh faktor genetik dari masing-masing genotipe serta lingkungan antara lain intensitas cahaya, temperatur, dan ketersediaan unsur hara. Keragaan karakter diameter batang tanaman tomat berbuah pipih dan bulat tidak terdapat perbedaan yang signifikan (Tabel 2). Tidak terdapat perbedaan rataan tinggi tanaman dan diameter batang pada genotipe M4 yang dievaluasi dengan pembanding.

Tabel 1. Rekapitulasi hasil sidik ragam karakter kuantitatif 15 genotipe tomat M4 dan pembanding

\begin{tabular}{|c|c|c|c|c|}
\hline Karakter & Genotipe & KK $(\%)$ & Rataan umum & Standard error \\
\hline Tinggi tanaman $(\mathrm{cm})$ & $* *$ & 10.88 & 105.35 & 25.25 \\
\hline Diameter batang $(\mathrm{cm})$ & $* *$ & 12.05 & 11.09 & 1.71 \\
\hline Umur berbunga (HST) & $* *$ & 18.48 & 26.57 & 5.67 \\
\hline Umur panen (HST) & $* *$ & 8.42 & 57.58 & 5.31 \\
\hline Jumlah buah per tanaman & $* *$ & 20.83 & 85.00 & 36.25 \\
\hline Bobot buah per tanaman $(\mathrm{g})$ & $* *$ & 23.97 & $1,569.85$ & 897.64 \\
\hline Persentase bobot buah pecah $(\%)$ & $* *$ & 37.68 & 498.43 & 469.60 \\
\hline Bobot perbuah (g) & $* *$ & 19.32 & 29.56 & 6.90 \\
\hline Panjang buah $(\mathrm{cm})$ & $* *$ & 13.17 & 29.39 & 6.08 \\
\hline Diameter buah $(\mathrm{cm})$ & $* *$ & 14.87 & 36.10 & 7.78 \\
\hline Padatan total terlarut ( ${ }^{\circ}$ Brix $)$ & $* *$ & 9.06 & 5.41 & 0.88 \\
\hline Kejadian penyakit & $* *$ & 24.50 & 37.17 & 28.38 \\
\hline Indeks pecah buah & $* *$ & 23.28 & 41.95 & 51.53 \\
\hline Produktivitas (ton ha-1) & $* *$ & 23.97 & 14.88 & 4.42 \\
\hline
\end{tabular}

Keterangan: $\mathrm{KK}=$ koefisien keragaman, $* *$ = nyata pada taraf $1 \%$ 
Umur berbunga pada tanaman untuk genotipe M4 berkisar antara 20-33 HST (Tabel 2). Hasil ini sesuai dengan Narziwan et al. (2014) bahwa seluruh galur tomat lokal memiliki umur berbunga 28-31 HST. Genotipe yang berbunga lebih awal biasanya akan dapat dipanen lebih cepat. Tomat yang berumur genjah (adalah tanaman yang dapat dipanen lebih cepat) sangat diminati oleh petani dan biasanya tanaman yang berbunga lebih cepat akan berbuah lebih cepat. Penelitian ini menunjukkan bahwa genotipe M4/495 Kemir1-4-7 (U3) dan M4/495 GL 2-8-10 (U2) sebagai genotipe tanaman tomat berbuah bulat dan pipih yang memiliki umur berbunga cepat dan umur panen genjah (Tabel 2). Umur panen buah tomat berbentuk pipih cenderung lebih cepat dari buah tomat berbentuk bulat.

Keragaan Karakter Jumlah Buah Per Tanaman, Panjang Buah, Diameter Buah, dan Padatan Terlarut Total Setiap Genotipe

Genotipe M4 memilki rataan jumlah buah per tanaman yang berbeda dengan genotipe pembanding. Genotipe M4 yang berbuah bulat lebih sedikit jumlah buah per tanaman dibanding dengan tomat berbuah pipih. Genotipe M4/495 Lombok 1-9-2 (U2) memiliki jumlah buah per tanaman paling banyak dari tanaman tomat yang berbuah bulat serta genotipe M4/495 STBGL 1-2-3 (U1) memiliki jumlah buah per tanaman paling banyak dari tanaman tomat berbuah pipih (Tabel 3). Karakter kuantitatif seperti jumlah buah per tanaman dikendalikan oleh banyak gen dan dipengaruhi oleh lingkungan (Syukur et al., 2012). Karakter-karakter yang terdapat pada tanaman secara terus menerus akan memberikan tanggapan dan penyesuaian terhadap lingkungannya, sehingga terjadi perbedaan antara yang satu dengan yang lainnya. Karakter panjang buah, diameter buah, dan padatan total terlarut tidak berbeda nyata antara genotipe yang diuji dengan pembanding baik yang berbuah bulat maupun pipih. Hal ini menunjukkan bahwa genotipe tidak memiliki perbedaan pada karakter tersebut.

Berbeda dengan hasil penelitian Gumelar et al. (2014) yang menyatakan bahwa karakter kuantitatif seperti panjang buah, diamater buah, dan bobot buah pertanaman cenderung dipengaruhi oleh genotipe, lingkungan, dan interaksi genetik x lingkungan. Sutjahjo et al. (2015) menyatakan bahwa diameter buah dipengaruhi oleh sifat genetik tanaman walaupun pertumbuhan dan perkembangan daun dipengaruhi oleh lingkungan, antara lain intensitas cahaya, temperatur, dan ketersediaan unsur hara.

Genotipe M4/495 Berlian 1-4-1 (U3) dan M4/495 CLN 1-2-2 (U3) memiliki rataan padatan total terlarut lebih tinggi dari Berlian (Tabel 3). Melly et al. (2012) menyatakan bahwa semakin masak buah tomat, semakin tinggi kandungan padatan total terlarut yang disebabkan karena degradasi pati (karbohidrat) menjadi gula sederhana. Varietas yang hasilnya tinggi, menyalurkan fotosintat lebih tinggi untuk pembentukan buah sehingga tidak cukup untuk membentuk padatan total terlarut pada buah.

Keragaan Karakter Persentase Bobot Buah Pecah, Indeks Pecah Buah, dan Kejadian Penyakit Setiap Genotipe

Pecah buah merupakan kejadian pecahnya kulit buah yang disebabkan oleh genetik dan sedikit pengaruh

Tabel 2. Tinggi tanaman, diameter batang, umur berbunga, dan umur panen pada 15 genotipe M4 dan 2 pembanding

\begin{tabular}{|c|c|c|c|c|}
\hline Genotipe & $\begin{array}{l}\text { Tinggi tanaman } \\
(\mathrm{cm})\end{array}$ & $\begin{array}{c}\text { Diamater batang } \\
(\mathrm{cm})\end{array}$ & $\begin{array}{c}\text { Umur berbunga } \\
\text { (HST) }\end{array}$ & $\begin{array}{c}\text { Umur panen } \\
\text { (HST) }\end{array}$ \\
\hline M4/495 Aceh 5- 4-10 (U1) & 88.00 & 1.05 & 29 & 59 \\
\hline M4/495 Berlian 1-4-1 (U3) & 85.67 & 1.12 & 25 & 55 \\
\hline M4/495 CLN 1-2-2 (U3) & 86.67 & 0.86 & 29 & 59 \\
\hline M4/495 Lombok 1-9-2 (U2) & 86.00 & 1.05 & 33 & 62 \\
\hline M4/990 Lombok 1-5-1 (U1) & 88.00 & 1.10 & 31 & 61 \\
\hline M4/495 Kemir1-4-7 (U3) & 90.67 & 1.07 & 20 & 50 \\
\hline M4/495 STBBK 1-2-3 (U3) & 107.67 & 1.08 & 25 & 55 \\
\hline M4/495 Lombok 4-1-3 (U2) & 84.00 & 0.88 & 26 & 57 \\
\hline M4/495 Lombok 4-1-3 (U3) & 83.00 & 0.99 & 27 & 57 \\
\hline M4/495 Lombok 1-2-2 (U2) & 132.33 & 1.17 & 28 & 59 \\
\hline M4/495 STBGL 1-2-3 (U1) & 143.33 & 1.25 & 26 & 57 \\
\hline M4/495 GL 2-8-10 (U2) & 128.67 & 1.33 & 22 & 52 \\
\hline M4/495 Kefaminano6-4-3 (U3) & 122.67 & 1.25 & 24 & 54 \\
\hline M4/990 Kudamati 1-1-1 (U1) & 141.33 & 1.28 & 29 & 59 \\
\hline M4/990 STBGL 1-2-9 (U1) & 126.67 & 1.01 & 24 & 54 \\
\hline Berlian & 52.67 & 0.91 & 22 & 52 \\
\hline Kefaminano 6 & 121.33 & 1.05 & 31 & 61 \\
\hline
\end{tabular}


Tabel 3. Jumlah buah, panjang buah, diameter buah, dan padatan terlarut total pada 15 genotipe M4 dan 2 pembanding

\begin{tabular}{lcccc}
\hline Genotipe & $\begin{array}{c}\text { Jumlah buah } \\
\text { per tanaman }\end{array}$ & $\begin{array}{c}\text { Panjang buah } \\
(\mathrm{cm})\end{array}$ & $\begin{array}{c}\text { Diameter buah } \\
(\mathrm{cm})\end{array}$ & $\begin{array}{c}\text { Padatan terlarut } \\
\text { total }\left({ }^{\circ} \text { Brix }\right)\end{array}$ \\
\hline M4/495 Aceh 5- 4-10 (U1) & $39 \mathrm{a}+$ & 4.28 & 3.86 & 5.44 \\
M4/495 Berlian 1-4-1 (U3) & $25 \mathrm{a}-$ & 3.95 & 3.34 & 6.32 \\
M4/495 CLN 1-2-2 (U3) & $19 \mathrm{a}-$ & 2.91 & 2.08 & 7.25 \\
M4/495 Lombok 1-9-2 (U2) & $54 \mathrm{a}+$ & 3.63 & 2.24 & 5.38 \\
M4/990 Lombok 1-5-1 (U1) & $41 \mathrm{a}+$ & 3.53 & 2.21 & 5.54 \\
M4/495 Kemir1-4-7 (U3) & $54 \mathrm{a}+$ & 3.07 & 3.12 & 4.82 \\
M4/495 STBBK 1-2-3 (U3) & $46 \mathrm{a}+$ & 2.91 & 2.37 & 5.39 \\
M4/495 Lombok 4-1-3 (U2) & $39 \mathrm{a}+$ & 3.14 & 2.93 & 4.80 \\
M4/495 Lombok 4-1-3 (U3) & $51 \mathrm{a}+$ & 3.32 & 2.95 & 4.69 \\
M4/495 Lombok 1-2-2 (U2) & $54 \mathrm{~b}+$ & 3.09 & 2.12 & 5.63 \\
M4/495 STBGL 1-2-3 (U1) & $62 \mathrm{~b}+$ & 3.65 & 2.59 & 5.26 \\
M4/495 GL 2-8-10 (U2) & $55 \mathrm{~b}+$ & 4.58 & 4.05 & 5.10 \\
M4/495 Kefaminano 6-4-3 (U3) & $59 \mathrm{~b}+$ & 3.69 & 2.60 & 5.00 \\
M4/990 Kudamati 1-1-1 (U1) & $59 \mathrm{~b}+$ & 4.40 & 3.91 & 5.07 \\
M4/990 STBGL 1-2-9 (U1) & $22 \mathrm{~b}-$ & 3.85 & 3.81 & 3.80 \\
\hline Berlian & 28 & 2.96 & 1.85 & 4.89 \\
Kefaminano 6 & 45 & & 5.86
\end{tabular}

Keterangan: Angka yang diikuti huruf a memiliki nilai tengah berbeda nyata dengan pembanding Berlian, diikuti huruf $\mathrm{b}$ memiliki nilai tengah berbeda nyata dengan Kefaminano 6. Tanda (-) lebih kecil, $(+)$ lebih besar pada uji Dunnett

lingkungan. Liebisch et al. (2009) menyatakan bahwa faktor abiotik seperti kelembaban udara tinggi, suhu siang hari $32^{\circ} \mathrm{C}$ dan malam hari $27^{\circ} \mathrm{C}$, cahaya, hujan, dan permeabilitas dinding sel menurun akibat kekurangan kalsium mendorong terjadinya pecah buah. Buah yang mengalami pecah buah termasuk kategori buah yang tidak layak pasar. Pecah buah tomat menyebabkan daging buah cepat membusuk. Kong et al. (2013) menyatakan bahwa suhu di atas $20^{\circ} \mathrm{C}$ menyebabkan kulit retak pada buah tin. Karakter persentase buah pecah terdapat perbedaan rataan dengan pembanding kecuali M4/495 CLN 1-2-2 (U3). Genotipe M4 yang berbuah pipih mempunyai lebih banyak buah yang pecah. Genotipe M4/990 Lombok 1-5-1 (U1) persentase bobot buah pecah yang paling rendah sehingga termasuk kategori sangat tahan (Tabel 4). Banyaknya buah yang pecah belum tentu memberikan skor indeks pecah buah tinggi karena indeks pecah buah dihitung berdasarkan besarnya kulit buah yang pecah. Indeks pecah buah tinggi terjadi pada buah tomat yang pipih pada buah yang dipanen.

Kejadian layu bakteri yang tinggi mengakibatkan penurunan produksi buah tomat. Penelitian menunjukkan adanya indikasi bahwa bentuk buah berhubungan dengan ketahanan terhadap serangan penyakit layu bakteri. Tanaman tomat genotipe M4 yang berbuah pipih lebih toleran terhadap serangan penyakit layu bakteri dibandingkan dengan tanaman yang bentuk buahnya bulat (Tabel 4). Genotipe M4 yang berbentuk pipih diindikasi memiliki gen ketahanan terhadap layu bakteri.

\section{Keragaan Karakter Bobot Setiap Buah, Bobot Buah per Tanaman dan Produktivitas Setiap Genotipe}

Genotipe M4/495 Aceh 5- 4-10 (U1) dan M4/990 Kudamati 1-1-1 (U1) memiliki ukuran buah yang paling besar. Tanaman tomat dengan buah berbentuk pipih memiliki tipe pertumbuhan indeterminat sehingga akan tetap tumbuh cabang meskipun sudah berbuah sehingga memiliki bobot buah per tanaman lebih tinggi dibandingkan dengan tanaman tomat berbuah bulat. Pembentukan cabang yang banyak akan diikuti dengan pembentukan bakal bunga. Banyaknya bakal bunga maka akan banyak pula buah yang dihasilkan. Bobot buah per tanaman paling tinggi yaitu M4/495 Lombok 19-2 (U2) dan M4/495 STBGL 1-2-3 (U1). Bobot buah per tanaman yang tinggi sebagai kriteria seleksi genotipe yang berdaya hasil tinggi. Penelitian ini menunjukkan bahwa bobot buah yang tinggi maka produktivitas juga tinggi (Tabel 5). 
Tabel 4. Persentase bobot buah pecah, indeks pecah buah, dan kejadian penyakit pada 15 genotipe M4 dan 2 pembanding

\begin{tabular}{|c|c|c|c|}
\hline Genotipe & Bobot buah pecah (\%) & Indeks pecah buah & Kejadian penyakit (\%) \\
\hline M4/495 Aceh 5- 4-10 (U1) & $9.52 \mathrm{a}-$ & 8.33AT & 25.00 \\
\hline M4/495 Berlian 1-4-1 (U3) & $13.65 \mathrm{a}-$ & 8.33AT & $20.00 \mathrm{a}-$ \\
\hline M4/495 CLN 1-2-2 (U3) & 25.95 & 11.62AR & $66.67 \mathrm{a}+$ \\
\hline M4/495 Lombok 1-9-2 (U2) & $41.34 \mathrm{a}+$ & $20.00 \mathrm{AR}$ & $1.67 \mathrm{a}-$ \\
\hline M4/990 Lombok 1-5-1 (U1) & $0.00 \mathrm{a}-$ & $0.00 \mathrm{ST}$ & $0.00 \mathrm{a}-$ \\
\hline M4/495 Kemir1-4-7 (U3) & $42.54 \mathrm{a}+$ & $27.08 \mathrm{R}$ & $0.00 \mathrm{a}-$ \\
\hline M4/495 STBBK 1-2-3 (U3) & $41.46 \mathrm{a}+$ & $20.66 \mathrm{R}$ & $68.33 \mathrm{a}+$ \\
\hline M4/495 Lombok 4-1-3 (U2) & $9.29 \mathrm{a}-$ & $35.68 \mathrm{R}$ & $8.33 \mathrm{a}-$ \\
\hline M4/495 Lombok 4-1-3 (U3) & 7.09a- & 6.94AT & $5.00 \mathrm{a}-$ \\
\hline M4/495 Lombok 1-2-2 (U2) & $67.66 b-$ & $31.82 \mathrm{R}$ & $1.67 \mathrm{~b}+$ \\
\hline M4/495 STBGL 1-2-3 (U1) & $68.13 b-$ & $136.26 \mathrm{SR}$ & 0.00 \\
\hline M4/495 GL 2-8-10 (U2) & $54.74 b-$ & $37.49 \mathrm{R}$ & 0.00 \\
\hline M4/495 Kefaminano 6-4-3 (U3) & $55.26 \mathrm{~b}-$ & $29.70 \mathrm{R}$ & $3.33 b+$ \\
\hline M4/990 Kudamati 1-1-1 (U1) & $58.54 b-$ & $36.62 \mathrm{R}$ & $8.33 \mathrm{~b}+$ \\
\hline M4/990 STBGL 1-2-9 (U1) & $57.62 b-$ & $34.32 \mathrm{R}$ & 0.00 \\
\hline Berlian & 27.64 & $12.22 \mathrm{AR}$ & 26.67 \\
\hline Kefaminano 6 & 74.31 & $31.14 \mathrm{R}$ & 0.00 \\
\hline
\end{tabular}

Keterangan: Angka yang diikuti huruf a memiliki nilai tengah berbeda nyata dengan pembanding Berlian, diikuti huruf $b$ memiliki nilai tengah berbeda nyata dengan Kefaminano 6. Tanda (-) lebih kecil, (+) lebih besar pada uji Dunnet; ST $=$ sangat tahan; $\mathrm{T}=$ tahan; $\mathrm{AT}=$ agak tahan; $\mathrm{AR}=$ agak rentan; $\mathrm{R}=$ rentan

Tabel 5. Bobot per buah, bobot buah per tanaman, dan produktivitas 15 genotipe M4 dan 2 pembanding

\begin{tabular}{lccc}
\hline Genotipe & $\begin{array}{c}\text { Bobot per buah } \\
(\mathrm{g})\end{array}$ & $\begin{array}{c}\text { Bobot buah } \\
\text { per tanaman }(\mathrm{g})\end{array}$ & $\begin{array}{c}\text { Produktivitas } \\
\left(\text { ton }^{-1}\right)\end{array}$ \\
\hline M4/495 Aceh 5- 4-10 (U1) & 37.98 & $936.98 \mathrm{a}+$ & $17.81 \mathrm{a}+$ \\
M4/495 Berlian 1-4-1 (U3) & 32.19 & 667.57 & 12.69 \\
M4/495 CLN 1-2-2 (U3) & 19.00 & $220.42 \mathrm{a}-$ & $4.19 \mathrm{a}-$ \\
M4/495 Lombok 1-9-2 (U2) & 27.54 & $986.12 \mathrm{a}+$ & $18.74 \mathrm{a}+$ \\
M4/990 Lombok 1-5-1 (U1) & 28.74 & $932.28 \mathrm{a}+$ & $17.72 \mathrm{a}+$ \\
M4/495 Kemir1-4-7 (U3) & 30.67 & $877.00 \mathrm{a}+$ & $16.67 \mathrm{a}+$ \\
M4/495 STBBK 1-2-3 (U3) & 18.32 & 668.26 & 12.70 \\
M4/495 Lombok 4-1-3 (U2) & 31.37 & $842.42 \mathrm{a}+$ & $16.01 \mathrm{a}+$ \\
M4/495 Lombok 4-1-3 (U3) & $708.78 \mathrm{a}+$ & 13.47 \\
M4/495 Lombok 1-2-2 (U2) & 24.72 & $871.71 \mathrm{~b}+$ & $16.57 \mathrm{~b}+$ \\
M4/495 STBGL 1-2-3 (U1) & 30.71 & $950.62 \mathrm{~b}+$ & $18.07 \mathrm{~b}+$ \\
M4/495 GL 2-8-10 (U2) & 28.61 & $850.41 \mathrm{~b}+$ & $16.16 \mathrm{~b}+$ \\
M4/495 Kefaminano 6-4-3 (U3) & 31.97 & $942.15 \mathrm{~b}+$ & $17.91 \mathrm{~b}+$ \\
M4/990 Kudamati 1-1-1 (U1) & 28.71 & $854.75 \mathrm{~b}+$ & $16.25 \mathrm{~b}+$ \\
M4/990 STBGL 1-2-9 (U1) & 40.03 & $710.24 \mathrm{~b}+$ & 13.50 \\
\hline Berlian & 24.87 & 604.46 & 11.49 \\
Kefaminano 6 & 28.77 & 680.08 & 12.93 \\
\hline
\end{tabular}

Keterangan: Angka yang diikuti huruf a memiliki nilai tengah berbeda nyata dengan pembanding Berlian, diikuti huruf $b$ memiliki nilai tengah berbeda nyata dengan Kefaminano 6. Tanda (-) lebih kecil, (+) lebih besar pada uji Dunnett 


\section{KESIMPULAN}

Genotipe yang sangat tahan pecah buah, persentase kejadian layu bakteri paling rendah, dan berdaya hasil tinggi adalah genotipe M4/990 Lombok 1-5-1 (U1). Genotipe yang memiliki persentase kejadian layu bakteri paling rendah adalah genotipe M4/495 STBGL 1-2-3 (U1), M4/495 GL 28-10 (U2), dan M4/990 STBGL 1-2-9 (U1). Genotipe yang berdaya hasil tinggi adalah M4/495 Lombok 1-9-2 (U2) dan M4/495 Aceh 5- 4-10 (U1).

\section{DAFTAR PUSTAKA}

Agrios, G.N. 1996. Ilmu Penyakit Tumbuhan Edisi ke-tiga. Gajah Mada University Press, Yogyakarta, ID.

Apriastika, P.A., I.M. Sudana, I.M. Sudarma. 2015. Hubungan sifat fisika dan kimia tanah dengan persentase penyakit layu pada tanaman cengkeh (Syzygium aromaticum L.) yang disebabkan oleh jamur akar putih (Rigidoporus sp.) di desa Unggahan Kabupaten Buleleng. E-J. Agroekoteknologi Trop. 4:293-296.

Cahyono, B. 2008. Usaha Tani dan Penanganan Pascapanen Tomat. Yogyakarta, ID.

Chahal, G.S., S.S. Gosal. 2006. Mutation breeding. in principles and procedure of plant breeding. Alpha Sicence International, New York.

Chaudhry, Z., H. Rashid. 2011. Isolation and characterization of Ralstonia solanacearum from infected tomato plants of Soan Skesar Valley of Punjab. Pak J. Bot. 43:2979-2985.

Damayanti, N., R.H. Murti, Toekidjo. 2007. Keragaman galur-galur tomat (Lycopersicon esculentum) M4 hasil iradiasi sinar gamma 60Co. Ilmu Pertanian $14: 34-45$.

Gumelar R.M., S.H. Sutjahjo, S. Marwiyah, A. Nindita. 2014. Karakterisasi dan respon pemangkasan tunas air terhadap produksi serta kualitas buah genotipe tomat lokal. J. Hort. Indonesia 5:73-83.

Gnanamurthy, S, D. Dhanavel, A.L.A. Chidambaram. 2012. Frequency in germination studies of chlorophyll mutants in effectiveness and efficiency using chemical mutagens. Int. J. Current Life Sci. 2:23-27.

Hossain, A., A. Jaime, T.A. Silva, M.V. Lozocskaya, P. Zvolinsky. 2012. High temperature combined with drought effect rainfed spring wheat and barley in South-Eastern Rusia. J. Bio. Sci. saudi. 19:473-487.
Kong, M., B. Lampinen, K. Shackel, C.H. Crisosto. 2013. Fruit skin side cracking and ostiole-end splitting shorten postharvest life in fresh figs (Ficus carica L.), but are reduced by deficit irrigation. Postharvest Biol. Technol. 85:154-161.

Lestari, E.G. 2012. Combination of somaclonal variation and mutagenesis for crop improvement. J. Agro. Biogen. 8:38-44.

Liebeisch, F., J.F.J. Max, G. Heine, W.J. Horst. 2009. Blossom-end rot and fruit cracking of tomato grown in net-covered greenhouses in central Thailand can partly be corrected by calcium and boron sprays. J. Plant Nutr. Soil Sci. 172:140-150.

Loreti, S., M. Fiori, D.D Simone, G. Falchi, A. Gallelli, A. Schiaffino, S.Ena. 2008. Bacterial wilt caused by Ralstonia solanacearum on tomato in Italy. Plant Pathol. 57:368.

Melly, N., Satriana, Martunis. 2012. Pengaruh pelapisan kitosin terhadap sifat fisik dan kimia tomat segar pada berbagai tingkat kematangan. J. Teknol. Industri Pert. Indonesia 4:1-8.

Nazirwan, A., Wahyudi, Dulbari. 2014. Karakterisasi koleksi plasma nutfah tomat lokal dan introduksi. Jurnal Penelitian Pertanian Terapan 14:70-75.

[Pusdatin] Pusat Data dan Sistem Informasi Pertanian. 2014. Ekspor dan impor komoditi pertanian subsektor hortikultura 2014. Jakarta Sekretariat Jenderal Kementerian Pertanian, Jakarta.

Sellammal, R., M. Maheswaran. 2013. Mutagenic effectiveness and efficiency based on chlorophyll mutations in M2 generations of Rathu Heenati and PTB33. Res. J. Agric. Sci. 4:428-430.

Sugito, A., H.A. Djatmiko, L. Soesanto. 2010. Penekanan nabati pada tanah tanaman tomat terkontaminasi Fusarium oxysporum lycopersici. J. Ilmu Pertanian Indonesia 12:13-18.

Suharjo, U.K., C. Herison, Fahrurrozi. 2010. Keragaan tanaman kentang varitas Atlantik dan Granola di dataran medium (600 m dpl) Bengkulu pasca iradiasi sinar gamma. Akta Agrosia 13:82-88.

Supriadi. 2011. Penyakit layu bakteri (Ralstonia solanacearum): Dampak, bioekologi, dan peran teknologi pengendaliannya. Pengembangan Inovasi Pertanian 4:279-293. 
Sutjahjo, S.H., C. Herison, I. Sulastrini, S. Marwiyah. 2015. Pendugaan keragaman genetik beberapa karakter pertumbuhan dan hasil pada 30 genotipe tomat lokal. J. Hort. 25:304-310.

Syukur, M., S. Sujiprihati, R. Yunianti. 2012. Teknik Pemuliaan Tanaman. Penebar Swadaya, Jakarta.
Vanitha, S.C., S.R. Niranjana, S. Umesha. 2009. Role of phenylalanine ammonia lyase and polyphenol oxidase in host resistance to bacterial wilt of tomato. J. Phytopathol. 157:552-557.

Zainal, A., A. Anwar, S. Ilyas, Sudarsono, Giyanto. 2011. Uji inokulasi dan respon ketahanan 38 genotipe tomat terhadap Clavibacter michiganensis subsp. Michigenensis. J. Agron. Indonesia 39:85-91. 